\title{
Liter per Microgram
}

National Cancer Institute

\section{Source}

National Cancer Institute. Liter per Microgram. NCI Thesaurus. Code C120815.

A unit of concentration equal to liter per microgram. 